\title{
Hydrograph Separation in the Headwaters of the Shule River Basin: Combining Water Chemistry and Stable Isotopes
}

\author{
Jiaxin Zhou, ${ }^{1,2}$ Jinkui Wu, ${ }^{1,2}$ Shiwei Liu, ${ }^{1,2}$ Guoxiong Zeng, \\ Jia Qin, ${ }^{1,2}$ Xiuna Wang, ${ }^{1,2}$ and Qiudong Zhao ${ }^{1,2}$ \\ ${ }^{1}$ Laboratory of Watershed Hydrology and Ecology, Cold and Arid Regions Environmental and Engineering Research Institute, \\ Chinese Academy of Sciences, Lanzhou 730000, China \\ ${ }^{2}$ State Key Laboratory of Cryospheric Science, Cold and Arid Regions Environmental and Engineering Research Institute, \\ Chinese Academy of Sciences, Lanzhou 730000, China \\ ${ }^{3}$ Shule River Basin Water Resources Administration of Gansu Province, Yumen 735200, China
}

Correspondence should be addressed to Jinkui Wu; jkwu@lzb.ac.cn

Received 25 December 2014; Revised 20 April 2015; Accepted 28 April 2015

Academic Editor: Fengjing Liu

Copyright ( 2015 Jiaxin Zhou et al. This is an open access article distributed under the Creative Commons Attribution License, which permits unrestricted use, distribution, and reproduction in any medium, provided the original work is properly cited.

The runoff components were identified in the headwater area of Shule River Basin, using isotopic and chemical tracing with particular focus on the temporal variations of catchment sources. A total of 95 samples, including precipitation, groundwater, and glacial meltwater, were collected and analyzed for stable water isotopes $\left({ }^{18} \mathrm{O}\right.$ and $\left.{ }^{2} \mathrm{H}\right)$ and major chemical ion parameters (potassium, sodium, calcium, magnesium, sulfate, chloride, and bicarbonate). Based on the isotope and water chemistry data, we applied end member mixing analysis (EMMA) to identify and quantify the major runoff generating sources and their contributions. The contributions of groundwater, precipitation, and glacial meltwater were $66.7 \%, 19.9 \%$, and $13.4 \%$, respectively. The study indicated that groundwater dominated runoff in the headwater area of Shule River Basin. The roles of glacier meltwater should be remarkable in water resource management in this basin. The uncertainties of the EMMA method were summarized and estimated via a classical Gaussian error propagation technique. Analyses suggested that the uncertainty in the measurement method was less important than that in the temporal and spatial variations of tracer concentrations. The uncertainty was sensitive when the difference between mixing components was small. Therefore, the variation of tracers and the difference of mixing components should be considered when hydrograph separation was applied in the basin.

\section{Introduction}

The quantification of catchment response to rainfall or snowmelt events in terms of water fluxes and chemical composition is an important issue in catchment hydrology. In particular, during flooding periods, different interacting processes occur that are spatially distributed within the catchment $[1,2]$. These processes are defined by physiographic characteristics. In addition, runoff generation depends on the initial state of the various hydrological reservoirs and on the characteristics of the hydrological input (precipitation or snowmelt). Due to these factors, it is difficult to identify the dominant runoff generation processes [3].
The water shortage and low use efficiency make china thirsty, and the loss of glacier and wetland in the western plateau will exaggerate this thirst in the future [4], while the same situation happens in other places of the world [5]. Therefore, it is important to understand the runoff generation mechanism. In arid or semiarid regions, water is a key factor affecting the biomass production. A better understanding of runoff generation processes as well as catchment function is important for improved water resources management [6]. The hydrograph separation technique using natural tracers, in which different runoff components are quantified according to their chemical signature, is a widely used method for investigating runoff generation processes at 
the catchment scale [7]. Isotopes were used to quantify the interaction of different end member in glaciated catchments for longer time periods (monthly) and/or larger catchment areas $\left(>1000 \mathrm{~km}^{2}\right)$ [8-10]. Isotope techniques can be easily and successfully used to study the origin and dynamics of surface water and groundwater, evaporation of water bodies, and mixing processes between various water sources [11-13]. To obtain both temporal and spatial origins, some investigations using stable isotopes associated with chemical tracers have been undertaken in several different basins [14, 15]. Hydrochemical tracers, such as $\mathrm{PH}$, electrical conductivity, or the concentration of different anions and cations [16], have been used to determine the origin of runoff components. In recent years, geochemical methods and environmental isotope techniques have been used increasingly to determine runoff components in various catchments under different environmental conditions $[17,18]$. In the arid and semiarid areas, a combination of hydrologic and environmental isotope methods $\left({ }^{18} \mathrm{O}, \mathrm{D}\right)$ has been proved to be a valuable tool for studying processes within the water cycle and in isotope hydrology [19-21].

One common tool to identify runoff sources and flux components and calculate their contributions to the stream discharge is end member mixing analysis (EMMA) [22]. EMMA techniques have been applied in varieties of studies, at both the plot and the catchment scales. Only few studies have applied EMMA in the arid or semiarid regions [23]. It has been applied in many studies to identify end members at small catchment scales that describe the vertical sequence of water storages to flow contribution. These vertical end members are, for example, rain, soil water, and groundwater [24] or overland flow, soil water, and hillslope water. Fewer studies have applied EMMA at larger catchment scales of hundreds or even thousands of square kilometers [25]. This approach is based on three mass conservations: one for water, one for isotopic tracer, and one for geochemical tracer. It allows separating the relative contribution of the different components, which correspond to different reservoirs or different contributive areas. The use of isotopic tracers allows separating the runoff hydrograph into preevent water and event water while the use of geochemical tracers allows identifying the three origins of the runoff components [26, 27].

There is a clear need to develop predictive capabilities related to the identification of runoff generating sources in large ungauged basins, particularly in emergent countries such as China [28]. Runoff generation and dynamics is an important issue in watershed and water resource management. On the one hand, knowledge about runoff generation processes and flow pathways is crucial for evaluating the vulnerability of surface and groundwater system [29]. On the other hand, such knowledge helps to develop and validate hydrological models. Since arid and semiarid basins usually have more severe natural conditions and scarcities of observation data, the application of isotope techniques in catchment hydrology study seems to be a more economic and helpful tool [30]. Understanding hydrological processes will significantly add our ability to evaluate potential tradeoffs between social development and water availability. We expect that scientific results will provide an insight for water resource and watershed management in a large-area.

In this study, we applied the EMMA method to identify and quantify the major runoff generating sources in a three end members' system. The objectives of this study are (1) to identify runoff producing sources using ${ }^{18} \mathrm{O}$ and chloride ion as tracers in the headwater area of the Shule River Basin, (2) to investigate the applicability of the EMMA method in semiarid catchments, (3) to calculate the contributions of the three components of runoff. We developed a conceptual hydrograph separation technique, namely, three components' mixing model. It is based on the steady-state mass balance equations of water and tracer fluxes in a catchment. In addition, uncertainties analyses were performed for the hydrograph separation.

\section{Study Areas}

The Shule River, the third largest inland rivers basin with the whole catchment area of approximately $14.21 \times 10^{4} \mathrm{~km}^{2}$, is located in the Western Qilian Mountains. The upstream of the Shule River (Figure 1), at $96.6^{\circ} \mathrm{E} \sim 99.0^{\circ} \mathrm{E}$ and $38.2^{\circ} \mathrm{N} \sim$ $40.0^{\circ} \mathrm{N}$, with the area of $1.14 \times 10^{4} \mathrm{~km}^{2}$ and the mean elevation of $3885 \mathrm{~m}$, is located in the Tianjun, Qinghai Province, Northeastern margin of the Tibetan Plateau. The mainstream annual runoff varying significantly during different years is $10.83 \times 10^{8} \mathrm{~m}^{3}$. The $53 \%$ of the total annual runoff concentrated between July and September. However, the runoff distributed unevenly over time. The runoff in spring and winter only makes up for $8.5 \%$ and $10 \%$, respectively. According to nearly 40 years' hydrological data of Changmabao gauge station, the annual runoff of dry years and wet years is $5.36 \times$ $10^{8} \mathrm{~m}^{3}$ and $15.07 \times 10^{8} \mathrm{~m}^{3}$, respectively.

In the headwater area of Shule River Basin, our study area, Gahe, at $96.49^{\circ} \mathrm{E} \sim 98.58^{\circ} \mathrm{E}$ and $38.02^{\circ} \mathrm{N} \sim 39.12^{\circ} \mathrm{N}$, with the area $4096 \mathrm{~km}^{2}$, there are 347 glaciers and the area of glaciers is $29.45 \mathrm{~km}^{2}$, which accounts for $0.72 \%$ of the headwater area (Figure 2). Glaciers are mainly distributed above elevation $4500 \mathrm{~m}$, which is located in Shule Nanshan and Tuolai Nanshan [31]. Annual sunshine time is 3033-3246 hours. The mean annual elevation is $4000 \sim 4500 \mathrm{~m}$. The mean annual air temperature is approximately $-5^{\circ} \mathrm{C}$, the annual precipitation is $100-300 \mathrm{~mm}$ and mainly falling between May and September, and annual evaporation is about $1200 \mathrm{~mm}$ [32]. The temperatures of the hottest month (July) and the coldest month (January) are $7.5^{\circ} \mathrm{C}$ and $-17.5^{\circ} \mathrm{C}$, respectively. The study area belongs to the continental arid desert climate region which is characterized by cold, dry winters and relative warm, wet summers [33]. In the growing season of May through September, the plentiful sunshine and rainfall $(80 \%$ of annual total precipitation) allows plants to grow efficiently.

The Quaternary sediments, comprising diluvial-alluvial, aeolian, and lacustrine deposits, form the main aquifers in the basin. These sediments are enriched in calcite, gypsum, and mirabilite in parts of the middle reaches, and soil salinization occurs widely in the middle and lower reaches. The depth to the water table is $5-10 \mathrm{~m}$. There formed 


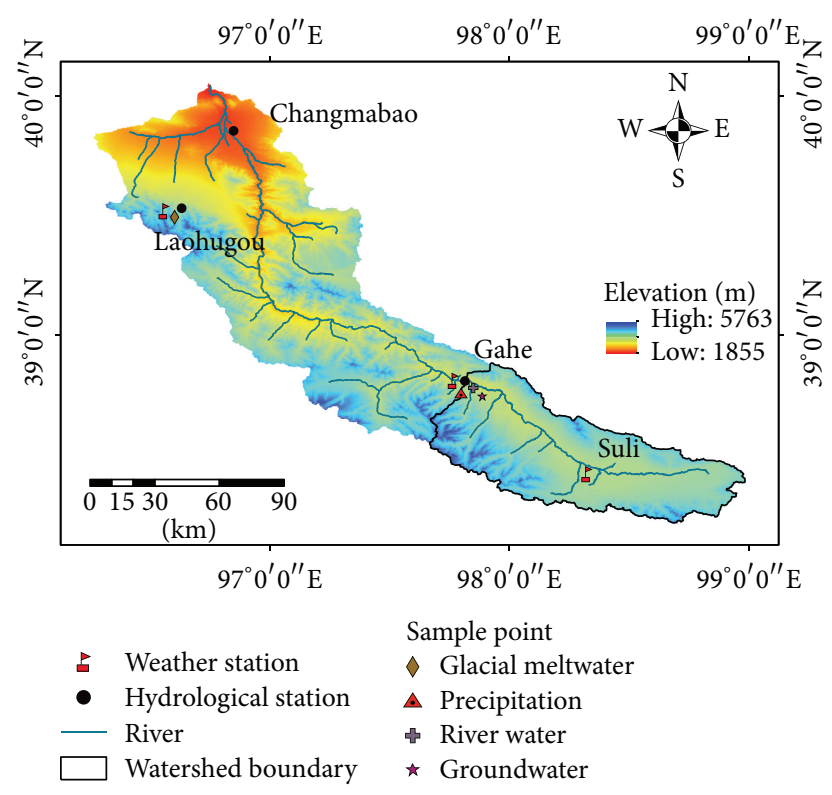

FIGURE 1: Site map showing the upstream of Shule River catchment and sampling sites.

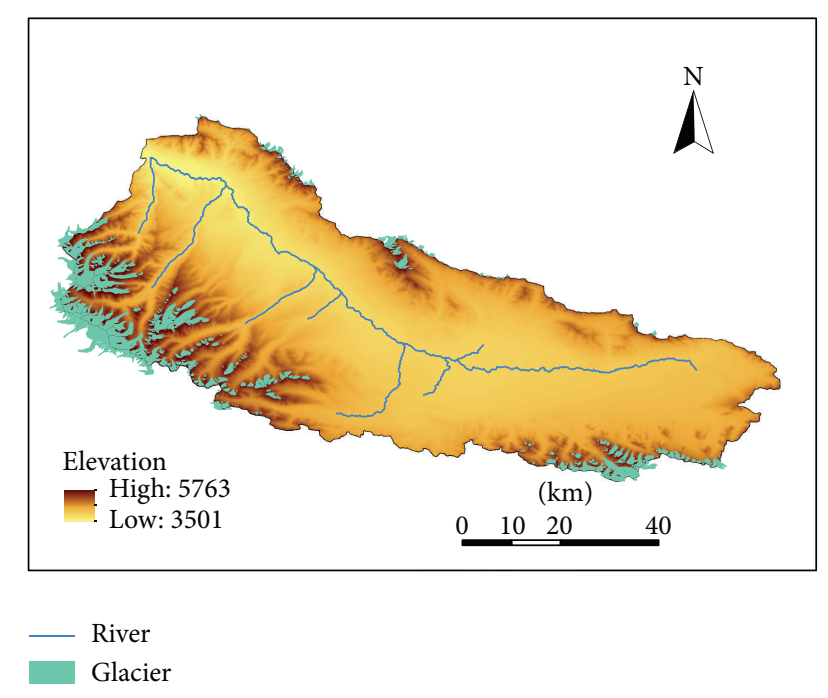

FIGURE 2: Glacier distribution of Gahe region.

a large area of swamp in the source places. The aquifer system includes a thick unconfined zone consisting of coarse-grained gravel, sand and a confined part consisting of medium to fine and silty sand. The landscape is characterized by large mountain ranges with steep valleys and gorges interspersed with relatively level and wide intermountain grassland basins [34].

\section{Material and Methods}

3.1. Field Sampling. Intensive synoptic sampling was carried out between April and September 2009 in Gahe, the headwater area of the Shule River, consisting of 95 samples.
Precipitation, glacial meltwater, groundwater, and river water were sampled. The number of four kinds of samples is precipitation 15 , river water 30 , groundwater 31 , and glacial meltwater 19, respectively. Precipitation, glacial meltwater, groundwater, and river water were sampled and analyzed for stable water isotopes $\left({ }^{18} \mathrm{O}\right.$ and $\left.{ }^{2} \mathrm{H}\right)$, major ion chemistry parameters as well. Samples were collected in polyethylene bottles and filtered through $0.45 \mathrm{~mm}$ Millipore membrane for major element analyses. Meteorological parameters and hydrology data were measured continuously by means of an automatic weather station and gauge station.

Precipitation samples were collected immediately after each precipitation event in order to minimize the alteration of heavy isotopes by evaporation with plastic basin sets. River water and groundwater samples were collected once a week. Due to the limitations of some nature conditions, we cannot get to glaciers distributed around Gahe. Hence, we collected the glacial meltwater samples in Laohugou Glacier number 12. Due to the background of the same atmospheric circulation, the moisture of the two sites comes from the same source. We considered the substitute is feasible.

3.2. Laboratory Analyses. All samples were kept in nearfrozen condition and transported to the State Key Laboratory of Cryospheric Science, Cold and Arid Regions Environmental and Engineering Research Institute, Chinese Academy of Sciences, for test.

Concentration of anions $\left(\mathrm{Cl}^{-}, \mathrm{SO}_{4}{ }^{2-}\right)$ was analyzed by Ion Chromatography (IC, DX-120, Dionex, Germany) while $\mathrm{HCO}_{3}{ }^{-}$and $\mathrm{CO}_{3}{ }^{2-}$ were analyzed by the titration method. Cations, $\mathrm{K}^{+}, \mathrm{Na}^{+}, \mathrm{Ca}^{2+}$, and $\mathrm{Mg}^{2+}$ were analyzed by using Atomic Absorption Spectroscopy (AAS) method. Every sample value represents the mean of two consecutive measurements. Measurement errors were less than $1 \%$. The detection limits of all ions were lower than $0.1 \mathrm{mg} / \mathrm{L}$. Chloride ion and ${ }^{18} \mathrm{O}$ were finally selected to assess the different contributing sources using mass balance equations and end member mixing diagrams.

The $\delta \mathrm{D}$ and $\delta^{18} \mathrm{O}$ composition of all water samples were analyzed by Liquid-Water Isotope Analyzer (DLT 100, Los Gatos, USA) based on off-axis integrated cavity output spectroscopy (OA-ICOS). Each sample is injected six times to avoid memory effect between samples. The isotopic ratios were expressed in per mil (\%o) units relative to Vienna Standard Mean Ocean Water (V-SMOW):

$$
\delta=\left(\frac{R_{\text {sample }}}{R_{\text {SMOW }}}-1\right) \times 10^{3}
$$

where $R$ is the ration ${ }^{18} \mathrm{O} /{ }^{16} \mathrm{O}$ or ${ }^{2} \mathrm{H} /{ }^{1} \mathrm{H}$. Precision of $\delta \mathrm{D}$ and $\delta^{18} \mathrm{O}$ was $\pm 0.6 \%$ and $\pm 0.2 \%$, respectively.

3.3. Hydrograph Separation Method and Uncertainties Analysis. In general, hydrograph separations are based on 
the steady-state mass balance equations of water and tracer fluxes in a catchment [34]. Following are the equations:

$$
\begin{gathered}
Q_{s}=Q_{g}+Q_{p}+Q_{m}, \\
Q_{s} \delta_{s}=Q_{g} \delta_{g}+Q_{p} \delta_{g}+Q_{m} \delta_{m}, \\
Q_{s} C_{s}=Q_{g} C_{g}+Q_{p} C_{p}+Q_{m} C_{m} .
\end{gathered}
$$

We converted the equations to vector form:

$$
\left[\begin{array}{l}
Q_{g} \\
Q_{p} \\
Q_{m}
\end{array}\right]=\left[\begin{array}{ccc}
1 & 1 & 1 \\
\delta_{g} & \delta_{p} & \delta_{m} \\
C_{g} & C_{p} & C_{m}
\end{array}\right]^{-1}\left[\begin{array}{c}
1 \\
\delta_{s} \\
C_{s}
\end{array}\right] Q_{s}
$$

Then the right side equations are divided by $Q_{s}$ :

$$
\left[\begin{array}{l}
\frac{Q_{g}}{Q_{s}} \\
\frac{Q_{p}}{Q_{s}} \\
\frac{Q_{m}}{Q_{s}}
\end{array}\right]=\left[\begin{array}{ccc}
1 & 1 & 1 \\
\delta_{g} & \delta_{p} & \delta_{m} \\
C_{g} & C_{p} & C_{m}
\end{array}\right]^{-1}\left[\begin{array}{c}
1 \\
\delta_{s} \\
C_{s}
\end{array}\right]
$$

where $Q$ is the discharge and $C$ and $\delta$ are the concentration of tracer chloride ion and ${ }^{18} \mathrm{O}$, respectively. Subscripts $s, g, p$, and $m$ refer to river water, groundwater, precipitation, and glacial meltwater, respectively. The application of these equations is based on certain assumptions, which are discussed, for instance, by Hinton et al. [35], Buttle [1], or Rodhe [36]:
(1) there is a significant difference between the tracer concentrations of the different components;

(2) the tracer concentrations are constant in space and time, or any variations can be accounted for;

(3) contributions of an additional component must be negligible, or the tracer concentrations must be similar to that of another component;

(4) the tracers must mix conservatively;

(5) the tracer concentrations of the components are not collinear.

Recent focus of hydrograph separation has been on uncertainty analysis. Several approaches are available for calculating uncertainty. Genereux (1998) suggested a general uncertainty propagation technique using Gaussian error estimators for two- and three-component separations [37]. However, an extensive overview of all possible causes of hydrograph separation uncertainties during different periods of a given event is still lacking. A classical Gaussian error propagation technique was applied to quantify the uncertainty of tracer-based hydrograph separations. This technique is generally used in other scientific and engineering problems. Errors of all separation equation variables are considered. Assuming that the uncertainty in each variable is independent of the uncertainty in the others, the relative error $W_{f}$ of the contribution of a specific runoff component is related to the uncertainty in each of the variables by the following [37]:

$$
\begin{aligned}
w_{y} & =\sqrt{\left(\frac{\partial y}{\partial x_{1}} w_{x 1}\right)^{2}+\left(\frac{\partial y}{\partial x_{2}} w_{x 2}\right)^{2}+\cdots+\left(\frac{\partial y}{\partial x_{n}} w_{x n}\right)^{2}}, \\
w_{f_{p}} & =\sqrt{\left[\frac{C_{e}-C_{s}}{\left(C_{e}-C_{p}\right)^{2}} w_{C_{p}}\right]^{2}+\left[\frac{C_{s}-C_{p}}{\left(C_{e}-C_{p}\right)^{2}} w_{C_{e}}\right]^{2}+\left[\frac{-1}{\left(C_{e}-C_{p}\right)} w_{C_{s}}\right]^{2}},
\end{aligned}
$$

where $w$ represents the uncertainty in the variable specified in the subscript, $c$ is the concentration of corresponding tracer, $e$ represents the event water, and $p$ represents the preevent water. In the results the relative error is given as percentage value.

It is demonstrated that large relative uncertainties must be considered for the quantification of runoff components. Uncertainties are caused by (1) tracer analysis and discharge measurement; (2) intrastorm variability of ${ }^{18} \mathrm{O}$; (3) elevation effect of ${ }^{18} \mathrm{O}$ and chloride; (4) solution of minerals during runoff formation; and (5) general spatial heterogeneity of tracer concentrations. The last source of error was the most significant. An investigation on the dominating runoff generation processes in the catchment, before a model is set up, would reduce such uncertainties.

\section{Results}

4.1. Temporal Variance of Runoff. The temporal variance of runoff is showed in Figure 3. The runoff showed a significant seasonal variation. The runoff varied in the range of 3.82 $338.09 \mathrm{~m}^{3} / \mathrm{s}$ with an average of $71.57 \mathrm{~m}^{3} / \mathrm{s}$. There is a minor peak in April since the snowmelt peak usually occurs in spring. We could see from the figure that most of peak flows were corresponding with the big rainfall events between June and September. It means the significant increase of runoff is the results of precipitation event. The average runoff is dominated by a snowmelt peak in spring followed by a decline in discharge over the growing season. From June to September, when most rainstorms occur, there is a considerable increase in discharge, followed by an again declining hydrograph until October, when the river itself freezes. 


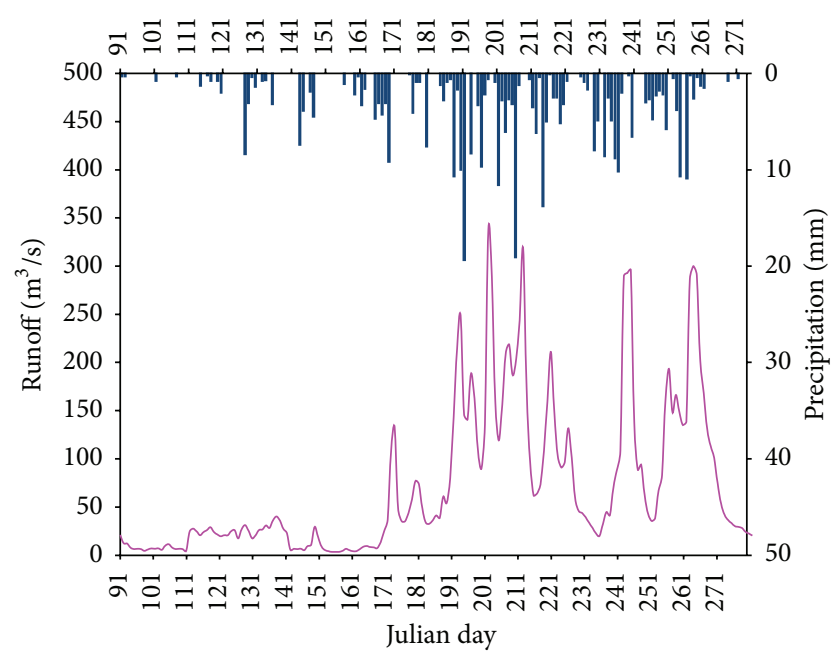

Figure 3: Runoff and rainfall from April to October 2009.

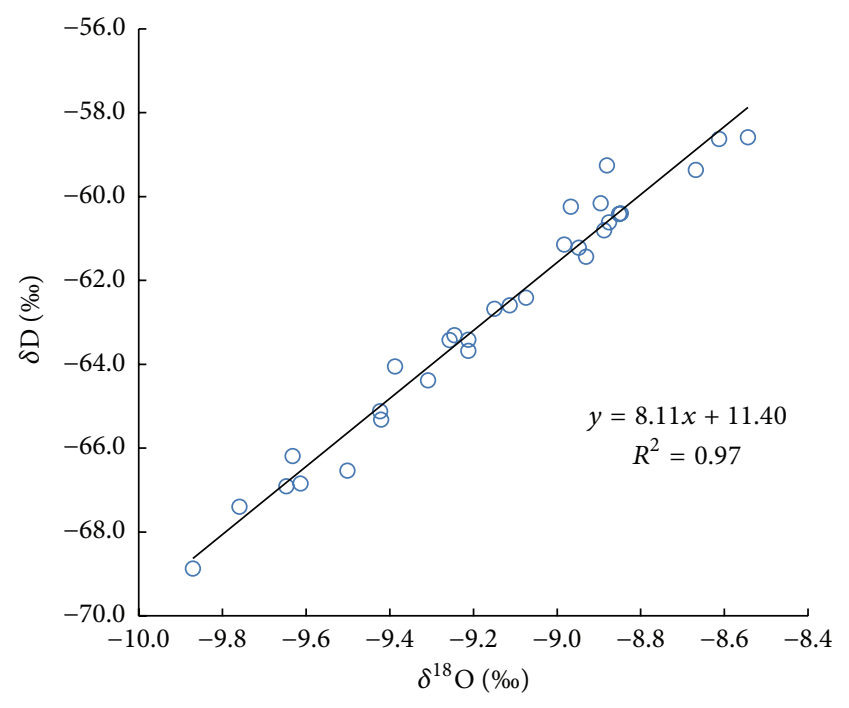

FIGURE 4: Stable isotope ( $\delta \mathrm{D}$ and $\left.\delta^{18} \mathrm{O}\right)$ compositions of river water.

\subsection{Isotopic Composition}

4.2.1. Isotopic Composition of River Water. The isotopic composition of river water during April and September in the Gahe station shows a steady variability, ranging from -9.9 to $-8.5 \%$ in $\delta^{18} \mathrm{O}$ and from -68.9 to $-58.2 \%$ in $\delta \mathrm{D}$, respectively. The possibility of differential isotopic evaporation of samples can be analyzed by comparing the samples to the meteoric water line which is formed by plotting $\delta \mathrm{D}$ against $\delta^{18} \mathrm{O}$ [38]. The local meteoric water line (LMWL) is commonly used as indicators of water vapor source, source of the humidity, and kinetic conditions in a number of fields including isotope hydrology [39]. The relationship between river water and the local meteoric water line (LMWL) was displayed by bivariate plot of $\delta^{18} \mathrm{O}$ versus $\delta \mathrm{D}$ (Figure 4). According to the distribution of river water in the space of $\delta^{18} \mathrm{O}$ versus $\delta \mathrm{D}$, most of the river water sample points were located approaching the local meteoric water line (LMWL) $(\delta \mathrm{D}=$ $\left.8.11 \delta^{18} \mathrm{O}+11.40, R^{2}=0.97, n=30\right)$. Also, the slope of the regression line was fairly close to the multiple-year observed values in Northwest China (7.88) and in Heihe River Basin, an inland river basin neighboring the study area (7.82) [40].

\subsubsection{Isotopic Signature of Precipitation, Groundwater, and} Glacial Meltwater. The isotopic composition of precipitation shows a relative significant variance. The values of $\delta^{18} \mathrm{O}$ fluctuate in $-13.0 \sim-8.3 \%$ and $-95.1 \sim-54.2 \%$ in $\delta \mathrm{D}$. The equation between $\delta^{18} \mathrm{O}$ and $\delta \mathrm{D}\left(\delta \mathrm{D}=7.68 \delta^{18} \mathrm{O}+9.29\right.$, $R^{2}=0.97, n=15$ ) (Figure 5(a)). The temporal and spatial variability of ${ }^{18} \mathrm{O}$ in precipitation are relatively high. This is caused by fractionation during evapotranspiration and condensation due to lower saturated vapor pressure of water molecules containing the heavier ${ }^{18} \mathrm{O}$ isotope than that of water molecules containing the lighter ${ }^{16} \mathrm{O}$ isotope. As a result, the $\delta^{18} \mathrm{O}$ in precipitation decreases with decreasing air temperature, increasing elevation, increasing latitude, increasing distance of vapor transport through the atmosphere, and increasing precipitation amounts.
The isotopic composition of groundwater ranges in -9.5 $-6.7 \%$ o (in $\delta^{18} \mathrm{O}$ ) and $-68.2 \sim-45.3 \%$ (in $\delta \mathrm{D}$ ). The equation between $\delta^{18} \mathrm{O}$ and $\delta \mathrm{D}\left(\delta \mathrm{D}=8.28 \delta^{18} \mathrm{O}+10.74, R^{2}=0.96\right.$, $n=31$ ) (Figure 5(b)). It is fairly close to that of river water. The value of $\delta^{18} \mathrm{O}$ ranges in $-14.7 \sim-12.3 \%$ and $\delta \mathrm{D}$ in $-105.0 \sim-85.1 \%$ o in glacial meltwater. The equation between $\delta^{18} \mathrm{O}$ and $\delta \mathrm{D}\left(\delta \mathrm{D}=7.55 \delta^{18} \mathrm{O}+7.34, R^{2}=0.96, n=\right.$ 19) (Figure $5(\mathrm{c})$ ). The stable isotope ratios of hydrogen and oxygen of water samples can provide essential information about water dynamics within a given watershed. In general, this is from isotope fractionation by evaporation, altitude effects, and different water sources they received [23]. The slope and the intercept of LMWL were slightly lower, showing drier and stronger local evaporation conditions. Evaporation caused a differential increase in the $\delta \mathrm{D}$ and $\delta^{18} \mathrm{O}$ values of the remaining water, resulting in a lower slope for the linear relationship between $\delta \mathrm{D}$ and $\delta^{18} \mathrm{O}$ values [41].

4.3. Temporal Variance of $\mathrm{Cl}^{-}$. It can be assumed that mixing processes in the catchment determine the isotopic concentration of total runoff. However, the hydrochemical composition of water is essentially changed as a result of interactions with organic and inorganic material during its passage through the unsaturated and saturated zones. The concentration of $\mathrm{Cl}^{-}$ in river water fluctuates in $9.4 \sim 13.4 \mathrm{mg} \cdot \mathrm{L}^{-1}$, with an average of $11.2 \mathrm{mg} \cdot \mathrm{L}^{-1}$. The variance of $\mathrm{Cl}^{-}$concentration has much relationship with runoff (Figure 6). In spring, the spring flood caused by snowmelt water makes the soil chemical ions into the river, so the concentration of $\mathrm{Cl}^{-}$is relatively high. Afterwards, with the increase of snowmelt water, glacier meltwater, and precipitation, the runoff has been showing a different amplitudes increase. With the increase of runoff, the dilution effect of ions has also increased, so the concentration of $\mathrm{Cl}^{-}$decreased. Although groundwater recharged, the dilution effect outweighs the supply effect. During August and September, the runoff has a considerable decrease; 


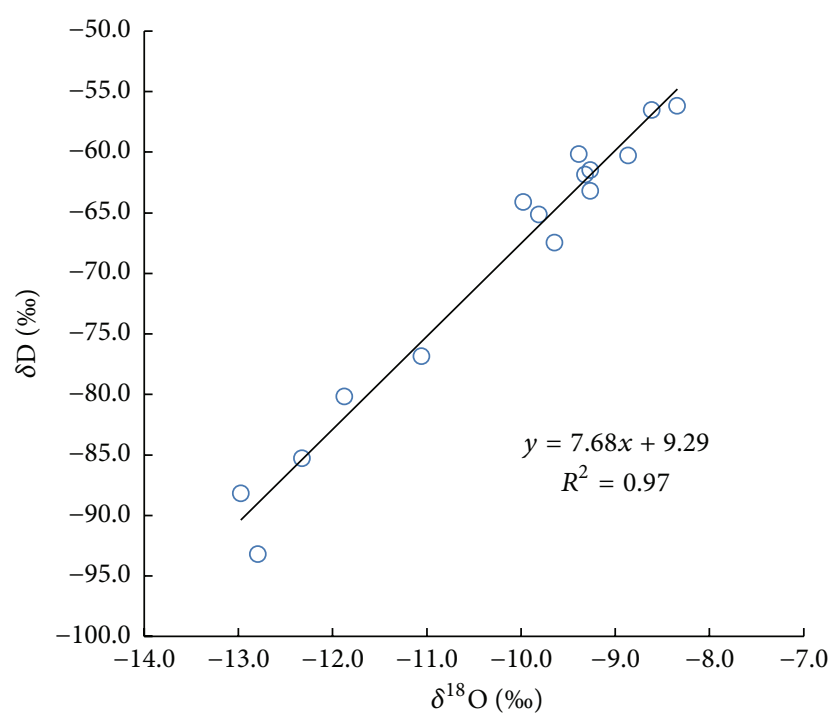

(a)

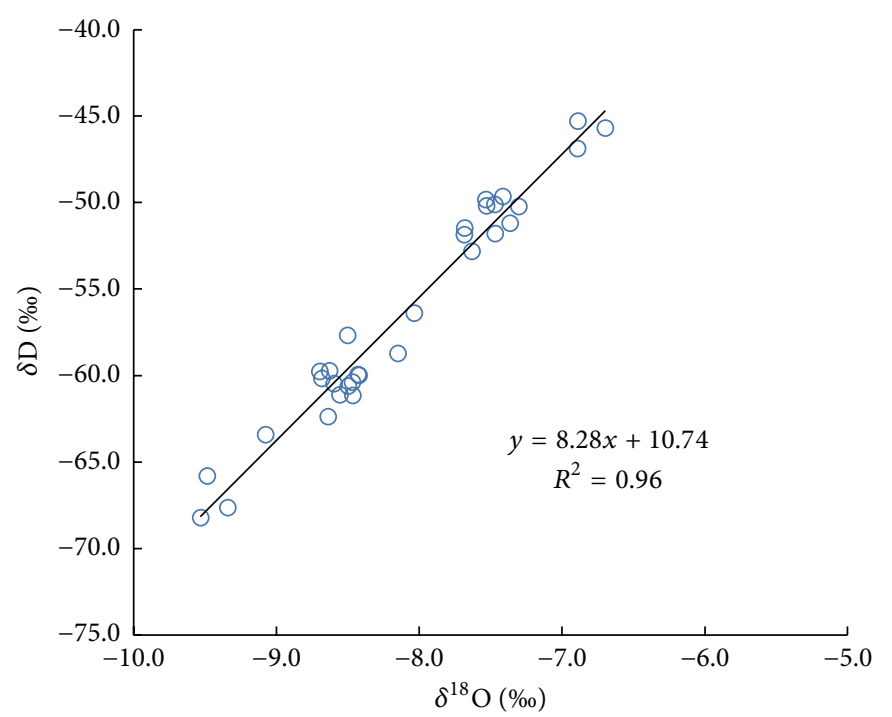

(b)

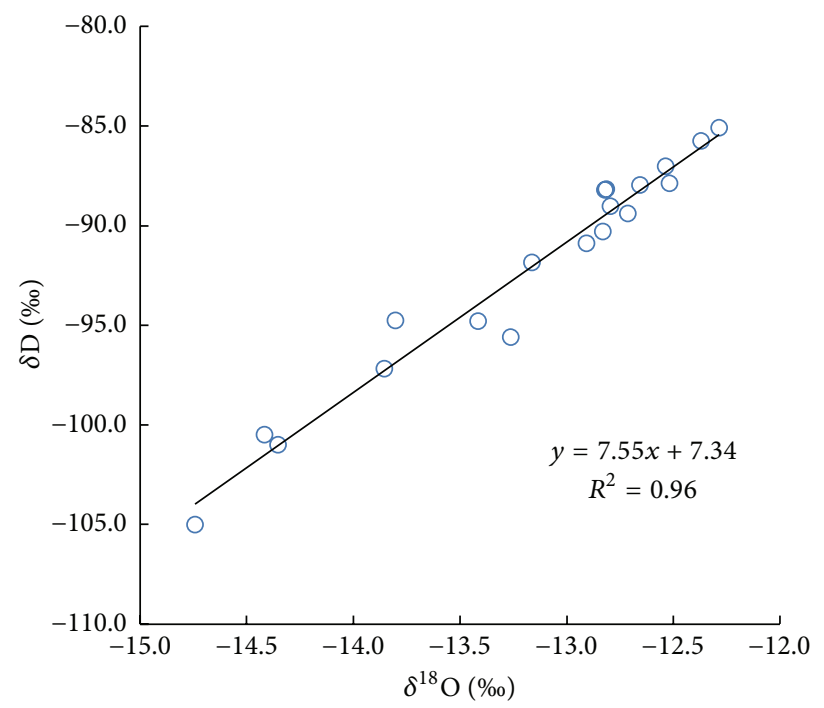

(c)

FIGURE 5: Stable isotope ( $\delta \mathrm{D}$ and $\left.\delta^{18} \mathrm{O}\right)$ compositions of precipitation (a), groundwater (b), and glacial meltwater (c).

the concentration of $\mathrm{Cl}^{-}$decreased because of the weakening of dilution effect.

4.4. Identification of End Members. Applying the method of geochemical and isotopic tracing, in this paper the runoff characteristics and hydrological law at the Gahe station are investigated at different periods in 2009. We conducted a performance of principal component analysis (PCA) on the concentration data of chloride ion. The results showed that the chemical tracer exhibits conservative behavior, whereas isotopes are geographical source tracers and only change composition due to slow fractionation processes [42]. ${ }^{18} \mathrm{O}$ belongs to the group of stable environmental isotopes occurring naturally in water. It has been widely used to separate storm flow into proportions of event and preevent water [1]. As part of the water molecule, ${ }^{18} \mathrm{O}$ behaves conservatively; that is, the combination of chemical and isotopic tracers allows identifying the origin of water pathways.

For the three-component hydrograph separation, the choice of a suitable tracer constellation to explain the chemical changes in discharge during a storm as well as to determine and to identify dominant sources, flow paths, and residence times in the catchment becomes increasingly important. The study suggests that hydrological tracer chlorine concentration and ${ }^{18} \mathrm{O}$ can be used under certain hydrological and lithological conditions. A system of algebraic equations is introduced that enables a three-component hydrograph separation by using ${ }^{18} \mathrm{O}$ and chlorine. These 
TABLE 1: Mean, maximum, minimum, and standard deviation values for the concentration of isotope and chloride ion in river water, precipitation, groundwater, and glacial meltwater.

\begin{tabular}{|c|c|c|c|c|c|c|c|c|c|c|c|c|}
\hline & \multicolumn{4}{|c|}{$\delta^{18} \mathrm{O}(\%)$} & \multicolumn{4}{|c|}{$\delta \mathrm{D}(\%)$} & \multicolumn{4}{|c|}{$\mathrm{Cl}^{-}\left(\mathrm{mg} \cdot \mathrm{L}^{-1}\right)$} \\
\hline & Mean & Max & Min & $\mathrm{SD}$ & Mean & Max & Min & $\mathrm{SD}$ & Mean & $\operatorname{Max}$ & Min & SD \\
\hline River water & -9.2 & -8.5 & -9.9 & 0.36 & -62.7 & -58.2 & -68.9 & 3.49 & 11.2 & 13.4 & 9.4 & 1.17 \\
\hline Precipitation & -10.2 & -8.3 & -13.0 & 1.56 & -69.7 & -54.1 & -95.1 & 12.5 & 0.5 & 0.8 & 0.2 & 0.22 \\
\hline Ground water & -8.1 & -6.7 & -9.5 & 0.76 & -56.4 & -45.3 & -68.2 & 6.44 & 16.3 & 19.7 & 11.0 & 2.20 \\
\hline Glacial meltwater & -13.2 & -12.3 & -14.7 & 0.73 & -92.1 & -85.1 & -105.0 & 5.63 & 2.2 & 3.2 & 1.2 & 0.56 \\
\hline
\end{tabular}

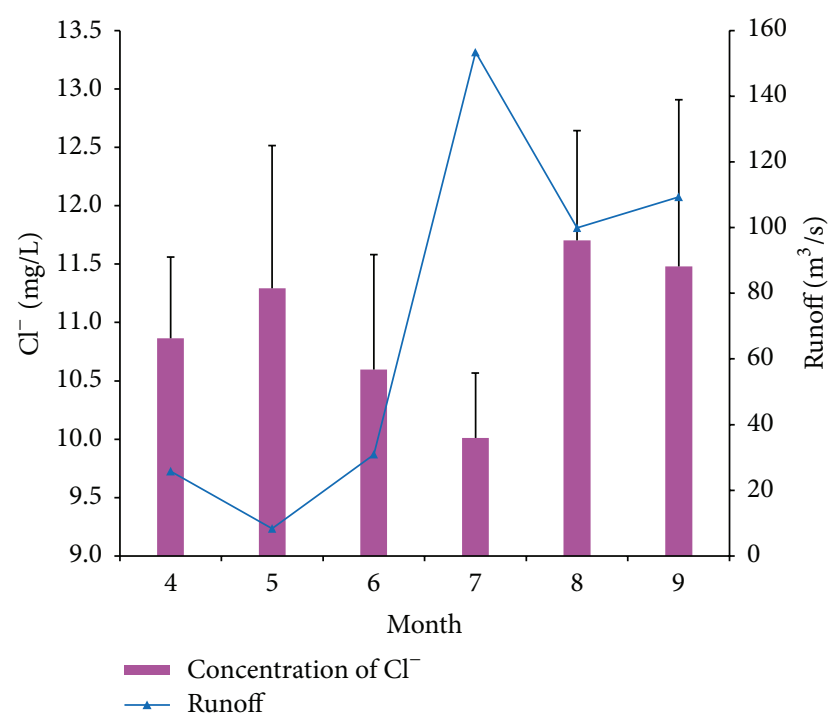

Figure 6: Monthly runoff and concentration of $\mathrm{Cl}^{-}$(with error bars).

alternative tracers should, however, be verified against more conventional tracers before use, as the behavior depends on specific characteristics of solutes.

The basic assumption in EMMA is that the stream water is a discrete mixture of its sources. The sources must therefore be of sufficiently different concentrations compared with the stream water. We projected the average values of tracer chloride ion and ${ }^{18} \mathrm{O}$ of three end members in triangle to test and verify the independence (Figure 7). It shows that most of stream water observations fall into the triangle that is spanned by three end members (precipitation, groundwater, and glacial meltwater). However, there exist some stream water observations that lie outside of the triangle. In many other studies that apply EMMA such a situation has been described $[14,22-24,35]$. These outliers result from a number of factors including (1) uncertainty in field sampling and laboratory analyses, (2) lack of temporal invariance of end members, or (3) the expression of different end member in the mixture as water source areas change temporally. Overall, the result can lead to over- or underprediction of the contributions of each end member to the stream water and should be understood as a source of uncertainty.

4.5. Contribution of End Members to Runoff. Owing to the geological and geomorphological genesis of the study

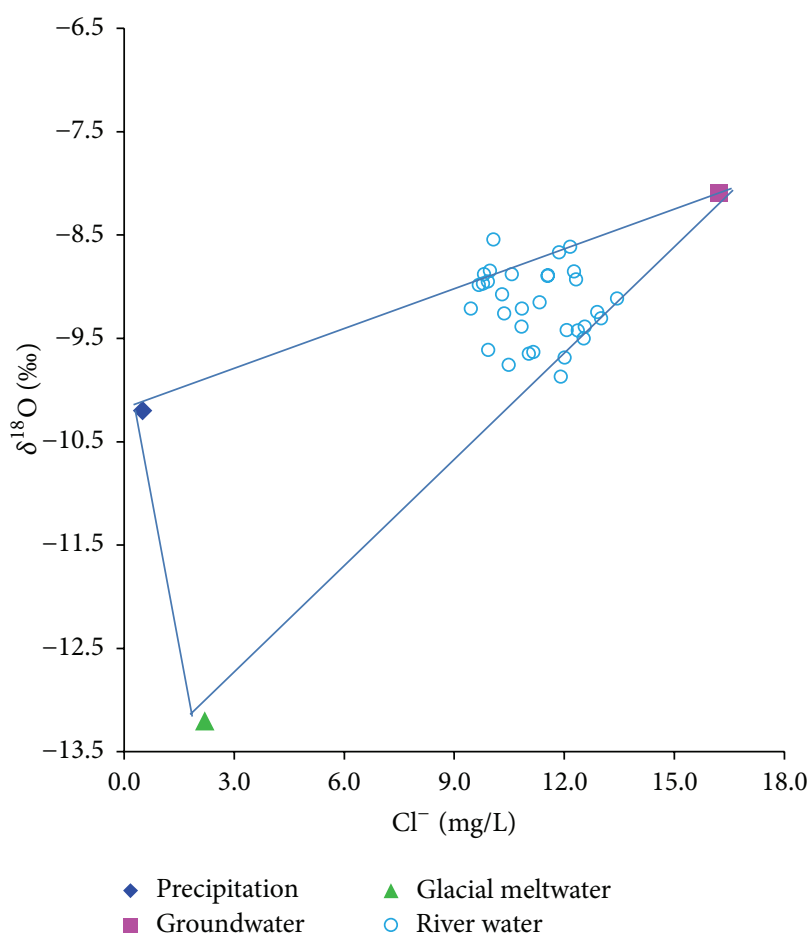

FIGURE 7: Stream water observations and the average values of tracers $\mathrm{Cl}^{-}$and ${ }^{18} \mathrm{O}$ of three end members that spanned the triangle.

site there are at least three runoff sources having distinct hydrological characteristics. Results obtained by the use of the three-component mixing model are shown in Figure 8. Based on the concentration data of isotope and chloride ion (Table 1), the contributions of each end member to river water were calculated according to the steady-state mass balance equations of water and tracer fluxes (equations (2)). Isotopic hydrograph separation shows that the contribution of groundwater, precipitation, and glacial meltwater is $66.7 \%$, $19.9 \%$, and $13.4 \%$, respectively. The study indicated that groundwater dominated runoff in the headwater area of Shule River Basin. And the roles of glacier meltwater should be significantly noticed in water resource management in this catchment. The glaciers are the headwaters of many rivers and they affect the water discharge of large rivers [43].

Despite the reasonable illustration of the qualitative behavior of runoff components, an exact quantification of runoff components contributing remained difficult and is strongly related to the determination of tracer concentrations 


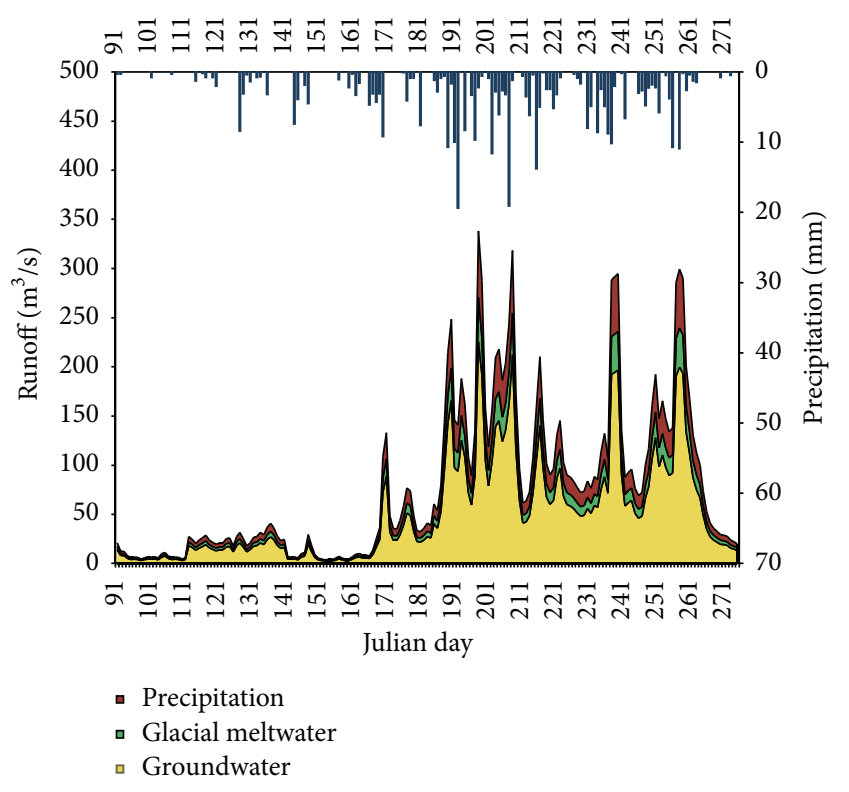

FIGURE 8: The conclusion of hydrograph separation.

in both runoff sources. Owing to the presence of various uncertainties, only qualitative results were achieved. Further experimental investigations are needed to define the tracer concentrations and their variability with greater accuracy. For hydrograph separations in larger scale basins, an extensive consideration of the spatial variability along with the superposition of spatially distributed runoff components is a challenging task for future research. Our results prompt us to focus future work on understanding interannual changes in end member contribution especially in semiarid regions.

\section{Discussion and Conclusions}

The isotopic and chemical values originate from measurement methods, field data, or the expert knowledge of the investigators. This is reasonable even if the implications of the effects are the same, since all of them cause an uncertain estimation of the end member concentrations and thus of the contribution of different runoff components. So-called end member concentrations need to be defined for every tracer of a specific runoff component for each separation time step in order to calculate the component proportions using mass balance equations for the tracers and the water. However, the determination of these concentrations is often problematic, as it has been shown that they may exhibit high temporal and spatial variability and always include errors caused by the analysis $[18,21]$. Therefore, the uncertainty of hydrograph separation results must be addressed. In general, large relative uncertainties must be considered while performing hydrograph separations. Predictive uncertainty is the primary impediment to progress in this area, but continued progress is being made to more fully quantify uncertainty and more fully explore its implications. The importance of reducing errors that have the largest impact on uncertainty is clearly demonstrated. Therefore, future investigations are needed to define with greater accuracy end member tracer concentrations and their spatial and temporal variability. Moving towards an understanding of uncertainties complexity is a challenging and important task for future research in catchment hydrology.

Assumed values of the uncertainty in isotopic composition were $w_{C_{s}}=0.2 \% 0, w_{C_{p}}=w_{C_{e}}=0.4 \%$ [43]. We calculated the uncertainty of tracers itself to be $9 \%$. Analyses suggested that the uncertainty in the measurement method was less important than that in the temporal and spatial variations of tracer concentrations. The uncertainty terms for precipitation were generally higher than $80 \%$ of the total uncertainty, indicating that the $\delta^{18} \mathrm{O}$ values of precipitation account for the majority of uncertainty. The uncertainty was sensitive when the difference between mixing components was small. Therefore, the variation of tracers and the difference of mixing components should be considered when hydrograph separation was applied in the basin.

Hydrograph separation shows that the contribution of groundwater, precipitation, and glacial meltwater is $66.7 \pm$ $6.02 \%, 19.9 \pm 1.79 \%$, and $13.4 \pm 1.20 \%$, respectively. There are 347 glaciers and the area of glaciers is $29.45 \mathrm{~km}^{2}$, which accounts for $0.72 \%$ of the headwater area. Under the background of global warming, rising temperature leads to the increase of snowmelt and accelerating the retreat of glaciers, which will have a significant impact on regional runoff. The roles of glacier meltwater should be significantly noticed in water resource management in this catchment. In addition to temporal variability, a superposition of spatial and temporal distributed runoff components needs to be considered. Moving towards an understanding of this complexity is a challenging and important task for future research in catchment hydrology.

Several studies compared the results of two- and threecomponent separation. Wenninger et al. (2004) showed a difference of $10 \%$ in preevent water contributions between the two methods, because the three-component separation accounted for snow and rain inputs together while the twocomponent separation accounted for rain inputs only [44]. Dense temporal sampling of hydrographs is often challenging especially at remote locations. Therefore studies that investigate runoff generation in alpine catchment are rare. Pionke et al. showed that for a $7.4 \mathrm{~km}^{2}$ watershed three of four monitored storms were dominated by preevent water (55-94\% in total) [45]. DeWalle showed that in a smaller catchment $\left(0.198 \mathrm{~km}^{2}\right)$ storm runoff was also dominated by preevent water contributions, $90 \%$ over the course of the hydrograph [46]. For a $45 \mathrm{~km}^{2}$ catchment, Buda found more than $80 \%$ preevent water contributions to the channel storm flow with $67 \%$ during the peak flow in a 6 ha catchment [47]. A similar range of preevent water contributions $(80 \%, 60 \%)$ was reported by Munyanzea et al. (2012) for two mesoscale catchments $\left(129.3 \mathrm{~km}^{2}, 257.4 \mathrm{~km}^{2}\right)$ in Rwanda [48]. Dong et al. have used the recursive digital filter method and smoothed minimum method to separate base flow based on daily runoff data from 1954 to 2009 in the upper reaches of the Shule River Basin, the recursive digital filter and smoothed minimum method were used for base flow separation. The base flow 
index is different between the calculation results from the two methods (0.77 and 0.66) [49].

One shortcoming of this study is that the identification of end members is limited to data collected during the vegetation period which comprises only 6 months of the year. Moreover, we only have the isotope data and chemical parameters of one hydrologic section, so we cannot analyze the spatial variability. The importance of reducing errors that have the largest impact is clearly demonstrated; therefore, a targeted sampling strategy is required. In order to fully characterize the range of climatic variability, our results emphasize the need of continued development of the longterm measurement. Our results prompt us to focus future work on understanding interannual changes in end member contribution especially in semiarid regions.

\section{Conflict of Interests}

The authors declare that there is no conflict of interests regarding the publication of this paper.

\section{Acknowledgments}

This research was financially supported by the National Natural Science Foundation of China (nos. 41130638; 41271085; 41401039). The authors are also grateful to all participants in the field (J. H. Yang, H. Wu) and in the laboratory (R. Xu) for their contribution which allows this study to progress in good conditions.

\section{References}

[1] J. M. Buttle, "Isotope hydrograph separations and rapid delivery of pre-event water from drainage basins," Progress in Physical Geography, vol. 18, no. 1, pp. 16-41, 1994.

[2] M. Bonell, "Selected challenges in runoff generation research in forests from the hillslope to headwater drainage basin scale," Journal of the American Water Resources Association, vol. 34, no. 4, pp. 765-785, 1998.

[3] S. Hoeg, S. Uhlenbrook, and Ch. Leibundgut, "Hydrograph separation in a mountainous catchment-combining hydrochemical and isotopic tracers," Hydrological Processes, vol. 14, no. 7, pp. 1199-1216, 2000.

[4] Z. S. Wang, C. F. Zhou, B. H. Guan et al., "The headwater loss of the western plateau exacerbates China's long thirst," AMBIO, vol. 35 , no. 5, pp. 271-272, 2006.

[5] B. G. Mark, "Hot ice: glaciers in the tropics are making the press," Hydrological Processes, vol. 16, no. 16, pp. 3297-3302, 2002.

[6] F. K. Barthold, J. Wu, K. B. Vaché, K. Schneider, H.-G. Frede, and L. Breuer, "Identification of geographic runoff sources in a data sparse region: hydrological processes and the limitations of tracer-based approaches," Hydrological Processes, vol. 24, no. 16, pp. 2313-2327, 2010.

[7] S. Uhlenbrook and S. Hoeg, "Quantifying uncertainties in tracer-based hydrograph separations: a case study for two-, three- and five-component hydrograph separations in a mountainous catchment," Hydrological Processes, vol. 17, no. 2, pp. 431453, 2003.
[8] J. Cable, K. Ogle, and D. Williams, "Contribution of glacier meltwater to streamflow in the Wind River Range, Wyoming, inferred via a Bayesian mixing model applied to isotopic measurements," Hydrological Processes, vol. 25, no. 14, pp. 2228 2236, 2011.

[9] Y. Kong and Z. Pang, "Evaluating the sensitivity of glacier rivers to climate change based on hydrograph separation of discharge," Journal of Hydrology, vol. 434-435, pp. 121-129, 2012.

[10] T. Pu, Y. He, G. Zhu, N. Zhang, J. Du, and C. Wang, "Characteristics of water stable isotopes and hydrograph separation in Baishui catchment during the wet season in Mt.Yulong region, south western China," Hydrological Processes, vol. 27, no. 25, pp. 3641-3648, 2013.

[11] C. Kendall and T. B. Coplen, "Distribution of oxygen-18 and deuteriun in river waters across the United States," Hydrological Processes, vol. 15, no. 7, pp. 1363-1393, 2001.

[12] F. J. Liu, M. Williams, and N. Caine, "Sources waters and flow paths in an alpine catchment, Colorado Front Range, USA," Water Resources Research, vol. 40, Article ID W09401, 2004.

[13] J. J. Gibson, T. W. D. Edwards, S. J. Birks et al., "Progress in isotope tracer hydrology in Canada," Hydrological Processes, vol. 19, no. 1, pp. 303-327, 2005.

[14] C. Wels, R. J. Cornett, and B. D. Lazerte, "Hydrograph separation: a comparison of geochemical and isotopic tracers," Journal of Hydrology, vol. 122, no. 1-4, pp. 253-274, 1991.

[15] P. Durand, M. Neal, and C. Neal, "Variations in stable oxygen isotope and solute concentrations in small sub-mediterranean montane streams," Journal of Hydrology, vol. 144, no. 1-4, pp. 283-290, 1993.

[16] N. C. Christophersen, C. Neal, R. P. Hooper, R. D. Vogt, and S. Andersen, "Modelling streamwater chemistry as a mixture of soilwater end- members-a step towards second-generation acidification models," Journal of Hydrology, vol. 116, no. 1-4, pp. 307-320, 1990.

[17] G. F. Pinder and J. F. Jones, "Determination of the groundwater component of peak discharge from the chemistry of total runoff," Water Resources Research, vol. 5, no. 2, pp. 438-445, 1969.

[18] J. J. McDonnell, M. Bonell, M. K. Stewart, and A. J. Pearce, "Deuterium variations in storm rainfall: implications for stream hydrograph separation," Water Resources Research, vol. 26, no. 3, pp. 455-458, 1990.

[19] W. G. Mook, "Environmental isotopes in the hydrological cycle, principles and applications, Volume III: surface water. International Hydrological Programme," Technical Documents in Hydrology 39, IAEA, Vienna, Austria, 2001.

[20] P. K. Aggarwal, "Isotope hydrology at the International Atomic Energy Agency," Hydrological Processes, vol. 16, no. 11, pp. 22572259, 2002.

[21] N. Christophersen and R. P. Hooper, "Multivariate analysis of stream water chemical data: the use of principal components analysis for the end-member mixing problem," Water Resources Research, vol. 28, no. 1, pp. 99-107, 1992.

[22] F. J. Liu, R. Parmenter, P. D. Brooks, M. H. Conklin, and R. C. Bales, "Seasonal and interannual variation of streamflow pathways and biogeochemical implications in semi-arid, forested catchments in Valles Caldera, New Mexico," Ecohydrology, vol. 1, no. 3, pp. 239-252, 2008.

[23] J. Chaves, C. Neill, S. Germer, S. G. Neto, A. Krusche, and H. Elsenbeer, "Land management impacts on runoff sources in small Amazon watersheds," Hydrological Processes, vol. 22, no. 12, pp. 1766-1775, 2008. 
[24] V. Acuña and C. N. Dahm, "Impact of monsoonal rains on spatial scaling patterns in water chemistry of a semiarid river network," Journal of Geophysical Research G: Biogeosciences, vol. 112, no. 4, Article ID G04009, 2007.

[25] B. Ladouche, A. Probst, D. Viville et al., "Hydrograph separation using isotopic, chemical and hydrological approaches (Strengbach catchment, France)," Journal of Hydrology, vol. 242, no. 3-4, pp. 255-274, 2001.

[26] D. Yang, C. Li, B. Ye et al., Chinese Perspectives on PUB and the Working Group Initiative. Predictions in Ungauged Basins: International Perspectives on the State of the Art and Pathways Forward, vol. 301, IAHS Publication, 2005.

[27] J. Klaus and J. J. McDonnell, "Hydrograph separation using stable isotopes: review and evaluation," Journal of Hydrology, vol. 505, pp. 47-64, 2013.

[28] C. H. Leibundgut, "Tracer-based assessment of vulnerability in mountainous headwaters," in Hydrology, Water Resources and Ecology in Headwaters, vol. 248, pp. 317-326, 1998.

[29] Z. Kattan, "Characterization of surface water and groundwater in the Damascus Ghotta basin: hydrochemical and environmental isotopes approaches," Environmental Geology, vol. 51, no. 2, pp. 173-201, 2006.

[30] W. Liu, S. Chen, X. Qin et al., "Storage, patterns, and control of soil organic carbon and nitrogen in the northeastern margin of the Qinghai-Tibetan Plateau," Environmental Research Letters, vol. 7, no. 3, Article ID 035401, 2012.

[31] M. J. Liu, T. D. Han, J. Wang et al., "Variations of the components of radiation in permafrost region of the upstream of Shule River," Plateau Meteorology, vol. 32, no. 2, pp. 411-422, 2013.

[32] Y. Sheng, J. Li, J. C. Wu, B. S. Ye, and J. Wang, "Distribution patterns of permafrost in the upper area of Shule River with the application of GIS technique," Journal of China University of Mining and Technology, vol. 39, no. 1, pp. 32-40, 2010.

[33] X. Xie, G. J. Yang, Z.-R. Wang, and J. Wang, "Landscape pattern change in mountainous areas along an altitude gradient in the upper reaches of Shule River," Chinese Journal of Ecology, vol. 29, no. 7, pp. 1420-1426, 2010.

[34] M. G. Sklash and R. N. Farvolden, "The role of groundwater in storm runoff," Journal of Hydrology, vol. 43, no. 1-4, pp. 45-65, 1979.

[35] M. J. Hinton, S. L. Schiff, and M. C. English, "Examining the contributions of glacial till water to storm runoff using two- and three-component hydrograph separations," Water Resources Research, vol. 30, no. 4, pp. 983-993, 1994.

[36] A. Rodhe, The origin of streamwater traced by oxygen-18 [Ph.D. thesis], Uppsala University, 1987, UNGI Report Series A No. 41.

[37] D. Genereux, "Quantifying uncertainty in tracer-based hydrograph separations," Water Resources Research, vol. 34, no. 4, pp. 915-919, 1998.

[38] A. L. James and N. T. Roulet, "Investigating the applicability of end-member mixing analysis (EMMA) across scale: a study of eight small, nested catchments in a temperate forested watershed," Water Resources Research, vol. 42, no. 8, Article ID W08434, 2006.

[39] W. Dansgaard, "Stable isotopes in precipitation," Tellus, vol. 16, no. 4, pp. 436-468, 1964.

[40] J. Jouzel, K. Froehlich, and U. Schotterer, "Deuterium and oxygen-18 in present-day precipitation: data and modelling," Hydrological Sciences Journal, vol. 42, no. 5, pp. 747-763, 1997.

[41] J. Wu, Y. Ding, B. Ye, Q. Yang, X. Zhang, and J. Wang, "Spatiotemporal variation of stable isotopes in precipitation in the
Heihe River Basin, Northwestern China," Environmental Earth Sciences, vol. 61, no. 6, pp. 1123-1134, 2010.

[42] J. K. Wu, Y. J. Ding, J. H. Yang et al., "Stable isotopes in different waters during melt season in Laohugou Glacial Catchment, Shule River basin, Northwestern China," Journal of Mountainous Science. In press.

[43] T. D. Yao, L. Thompson, W. Yang et al., "Different glacier status with atmospheric circulations in Tibetan Plateau and surroundings," Nature Climate Change, vol. 2, pp. 663-667, 2012.

[44] J. Wenninger, S. Uhlenbrook, N. Tilch, and C. Leibundgut, "Experimental evidence of fast groundwater responses in a hillslope/floodplain area in the Black Forest Mountains, Germany," Hydrological Processes, vol. 18, no. 17, pp. 3305-3322, 2004.

[45] H. B. Pionke, W. J. Gburek, and G. J. Folmar, "Quantifying stormflow components in a Pennsylvania watershed when ${ }^{18} \mathrm{O}$ input and storm conditions vary," Journal of Hydrology, vol. 148, no. 1-4, pp. 169-187, 1993.

[46] D. R. Dewalle and B. R. Swistock, "Differences in oxygen-18 content of throughfall and rainfall in hardwood and coniferous forests," Hydrological Processes, vol. 8, no. 1, pp. 75-82, 1994.

[47] A. R. Buda and D. R. DeWalle, "Dynamics of stream nitrate sources and flow pathways during stormflows on urban, forest and agricultural watersheds in central Pennsylvania, USA," Hydrological Processes, vol. 23, no. 23, pp. 3292-3305, 2009.

[48] O. Munyaneza, J. Wenninger, and S. Uhlenbrook, "Identification of runoff generation processes using hydrometric and tracer methods in a meso-scale catchment in Rwanda," Hydrology and Earth System Sciences, vol. 16, no. 7, pp. 1991-2004, 2012.

[49] W. W. Dong, Y. J. Ding, and X. Wei, "Variation of the base flow and its causes in the upper reaches of the Shule River in the Qilian Mountains," Journal of Glaciology and Geocryology, vol. 36, no. 3, pp. 661-669, 2014. 

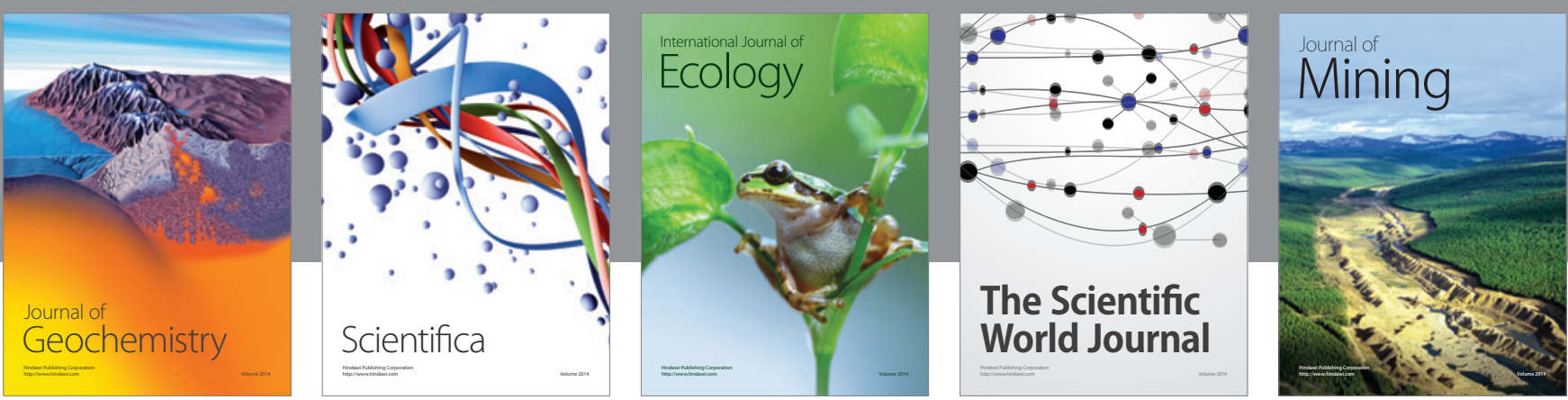

The Scientific World Journal
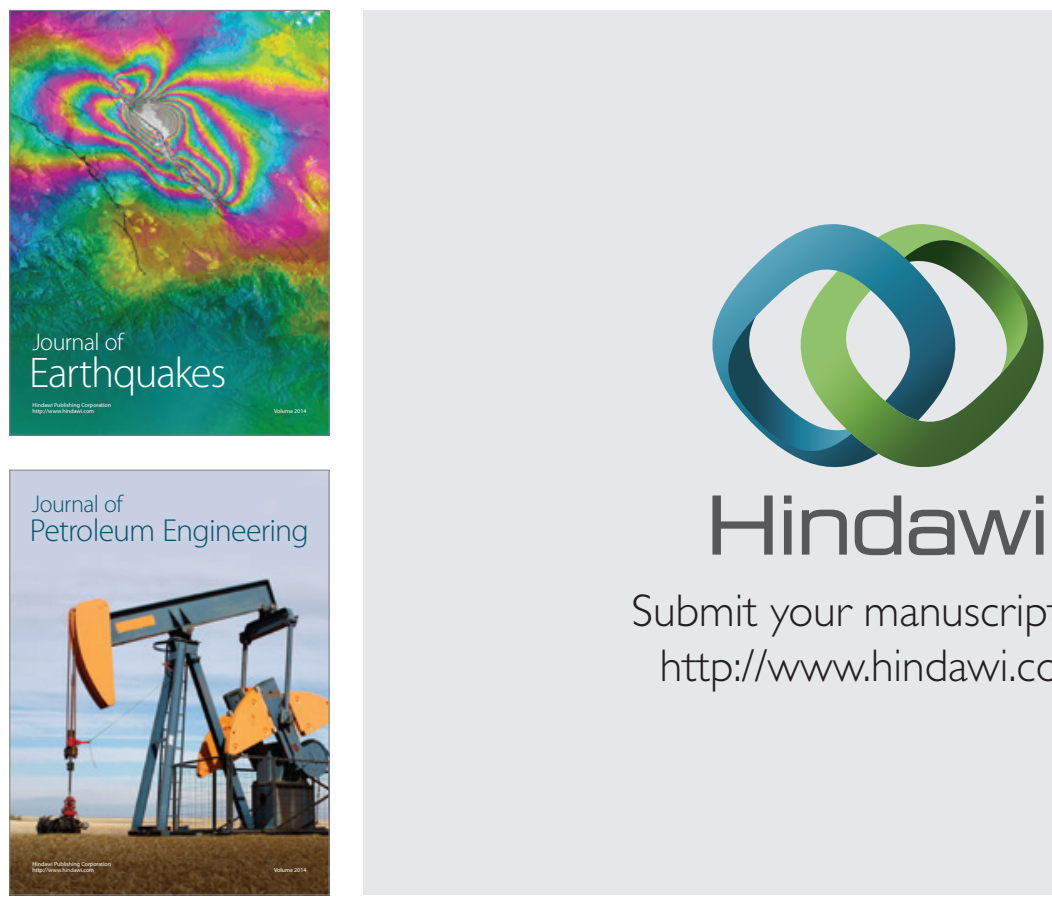

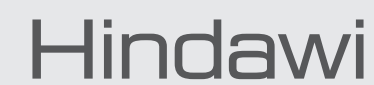

Submit your manuscripts at

http://www.hindawi.com
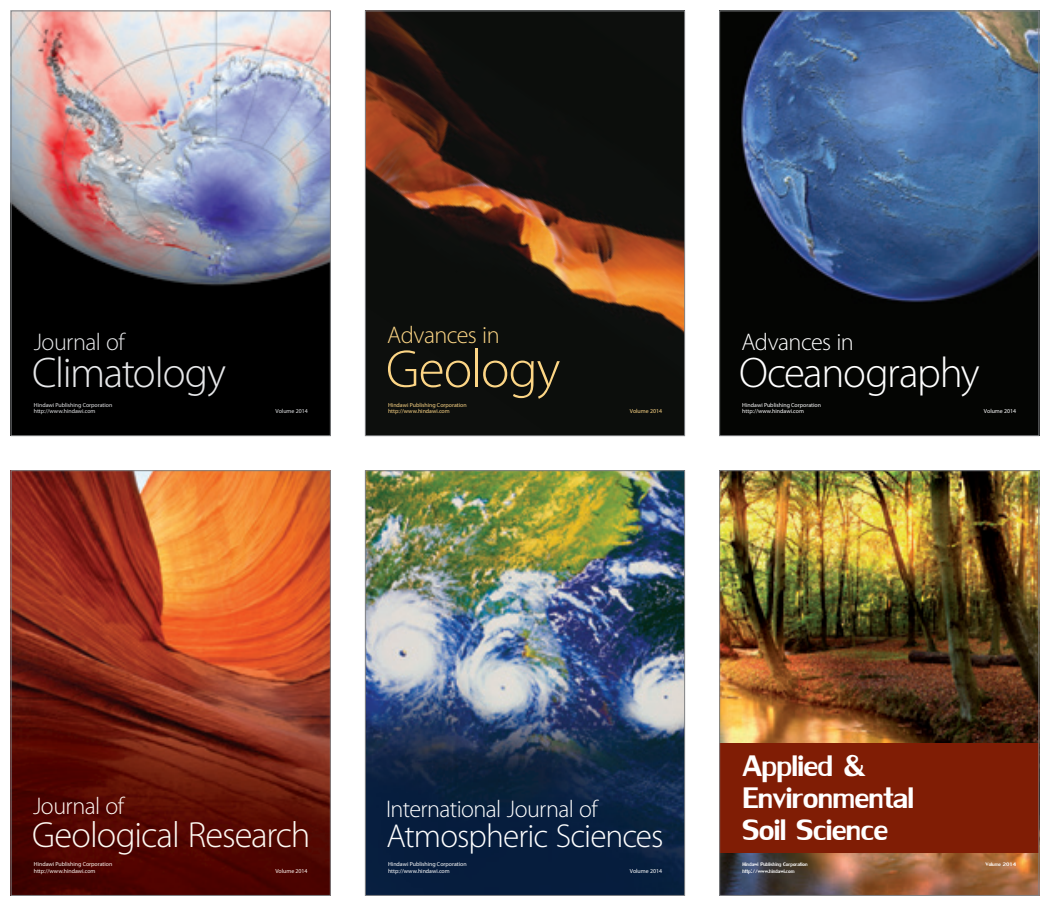
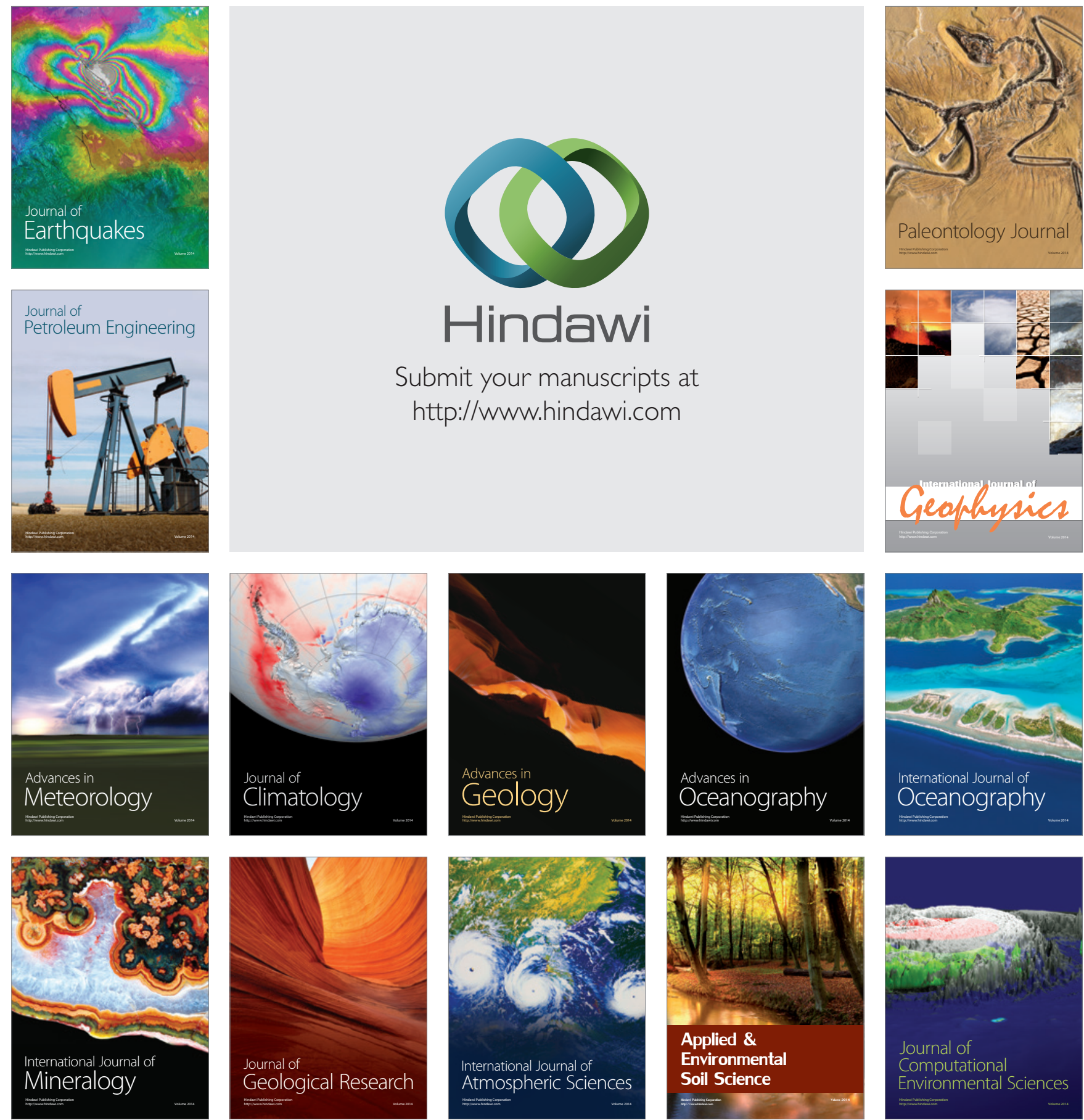